\title{
A EVOLUÇÃO DO CONSTITUCIONALISMO NO BRASIL E A ATUAÇÃO CONTEMPORÂNEA DOS TRIBUNAIS DE CONTAS
}

\author{
THE EVOLUTION OF CONSTITUTIONALISM IN BRAZIL
}

AND THE PERFORMANCE OF CONTEMPORARY COURTS OF ACCOUNTS

Wilber Carlos dos Santos Coimbra ${ }^{1}$

SUMÁRIO: Introdução; 1. Vertentes históricas do Constitucionalismo; 2. O Constitucionalismo brasileiro; 3. A criação dos Tribunais de Contas como elemento do constitucionalismo brasileiro; 3.1. Do Controle Externo e o desdobramento de suas atribuições ao longo da evolução constitucional brasileira; 4. Da atuação contemporânea dos Tribunais de Contas; Considerações Finais; Referências das fontes citadas.

\section{RESUMO}

O presente artigo, alcançado por pesquisa bibliográfica, buscou demonstrar a evolução do constitucionalismo brasileiro e a atuação contemporânea dos Tribunais de Contas, estes como órgãos ideados pelo Poder Constituinte, à luz da dogmática contemporânea aplicável sobre tais vertentes. O surgimento das Cortes de Contas no Brasil guarda perfeita sincronia com as nuances do constitucionalismo moderno e contemporâneo, uma vez que a nova ordem constitucional, reproduzindo regras de outrora, atribui-Ihes competências para fiscalizar a transparência do dispêndio dos dinheiros públicos, inserindo a correta e econômica aplicação, além da publicação ampla de tais execuções para conhecimento popular; há, ainda, competência das Cortes de Contas para atuar na inibição preventiva de improbidade administrativa e de dano ao erário, podendo expedir tutelas de urgência, sempre que latente o receio de ameaça ou indícios de violação do bem público, competência esta decorrente da evolução constitucional do poder geral de cautela conferido pela CRFB/88.

1 Doutorando DINTER - Faculdade Católica de Rondônia, Mestre em Gestão e Desenvolvimento Regional pela Universidade de Taubaté/SP, Especialista em Direito Administrativo pela Universidade Gama Filho/RJ, Conselheiro do Tribunal de Contas do Estado de Rondônia; Presidente da Escola Superior de Contas do Estado de Rondônia. Professor do Centro Universitário São Lucas. Porto Velho/RO, Brasil. conselheiro.wilbercoimbra@hotmail.com. 
SANTOS COIMBRA, Wilber Carlos dos. A evolução do constitucionalismo no brasil e a atuação contemporânea dos tribunais de contas. Revista Eletrônica Direito e Política, Programa de PósGraduação Stricto Sensu em Ciência Jurídica da UNIVALI, Itajaí, v.10, n.3, $2^{\circ}$ quadrimestre de 2015. Disponível em: www.univali.br/direitoepolitica - ISSN 1980-7791.

PALAVRAS-CHAVE: Constitucionalismo; Evolução constitucional brasileira; Tribunais de Contas.

\section{ABSTRACT}

This article, reached by literature, sought to demonstrate the evolution of Brazilian constitutionalism and contemporary performance of the Courts of Accounts, as these organs devised by the constituent power, in the light of contemporary dogmatic appropriate to such aspects. The emergence of Courts of Accounts in Brazil holds perfect sync with the nuances of modern and contemporary constitutionalism, once the new constitutional order, reproducing rules of yore, provides them powers to monitor the transparency of the expenditure of public funds by entering the correct and economic application, plus the wide publication of such executions to popular knowledge; there is also responsibility of the Courts of Accounts to act in preventive inhibition of the improper conduct and the damage to the public treasury, and it may issues emergency guardianships acts, whenever latent misgiving of a threat or evidence of a violation of the public values, a competence due to constitutional development the general power of vigilance conferred by CRFB / 88.

KEYWORDS: Constitutionalism; Brazilian constitutional evolution; Courts of Accounts.

\section{INTRODUÇÃO}

O constitucionalismo se qualifica como um movimento social, formado por uma concepção uníssona da população, e visa impor ao Estado, que garanta em documento político supremo, a organização dos Poderes do Estado, sua nítida separação entre seus Poderes, o regime de governo, a forma de Estado, a promoção e a declaração de direitos e garantias individuais fundamentais da pessoa humana para limitar o poder de atuação do Estado. Muito embora, em sua origem, o movimento constitucionalista tivesse garantido plena liberdade, sobretudo, com as liberdades negativas estatais, havia o exercício do uso excessivamente individual do direito de propriedade, mormente pelo absenteísmo estatal.

A Constituição, resultado dos primórdios do constitucionalismo formal originário, era vista muito mais como um documento político que propriamente um documento jurídico, vinculante e obrigatório, passando por várias transformações 
SANTOS COIMBRA, Wilber Carlos dos. A evolução do constitucionalismo no brasil e a atuação contemporânea dos tribunais de contas. Revista Eletrônica Direito e Política, Programa de PósGraduação Stricto Sensu em Ciência Jurídica da UNIVALI, Itajaí, v.10, n.3, $2^{\circ}$ quadrimestre de 2015. Disponível em: www.univali.br/direitoepolitica - ISSN 1980-7791.

ao longo da histórica. O constitucionalismo moderno e contemporâneo inconformado com a formalidade da norma e também com o seu teor material surge com as matizes dos direitos sociais para produzir resultados sociais eficientes, eficazes e efetivos.

Nesse panorama, na concretização das políticas públicas irradiadas do novo constitucionalismo, na gênese do século XIX, surge no Brasil um órgão de notória qualificação técnica para atuar na fiscalização do emprego dos recursos públicos, despendidos para concretizar a vontade estatal, posto, já aí, exigia-se resultado na prestação dos serviços executados pelo Estado, que tinha toda a sociedade como meta-fim.

Positivado na Constituição Federal de 1891, o Tribunal de Contas da União, no entanto, pela nova concepção do constitucionalismo, em que o Estado não mais podia contentar-se em promover igualdade formal, e sim, tinha o dever de efetivamente concretizar a igualdade social, o constituinte da primeira Constituição republicana fez inserir em seu art. $89^{2}$ a instituição do Tribunal de Contas, cuja competência era a liquidação das contas da receita e despesa e verificar a sua legalidade, antes de serem prestadas ao Congresso Nacional.

Mantendo-se as vertentes complexas, o constitucionalismo brasileiro traz fleches do constitucionalismo americano, francês e grego-romano para ancorar suas bases jurídico-filosóficas. Fincadas as premissas históricas, conceitua-se o instituto, onde se constata que, desde a Carta de 1824, ainda no período imperial, já se promoveu a delimitação de poderes políticos do Estado, a repartição de competência dos órgãos estatais, bem como a declaração de direitos, fundamentais e sociais, qualificados como vetores-matrizes, também irradiados na vigente Constituição de 1988.

\footnotetext{
2 Art 89 - É instituído um Tribunal de Contas para liquidar as contas da receita e despesa e verificar a sua legalidade, antes de serem prestadas ao Congresso. Os membros deste Tribunal serão nomeados pelo Presidente da República com aprovação do Senado, e somente perderão os seus lugares por sentença. BRASIL. Constituição da República Federativa do Brasil de 1981. Disponível em: http://www.planalto.gov.br/ccivil_03/Constituicao/Constituicao91.htm. Acesso em: 05 de julho de 2015.
} 
SANTOS COIMBRA, Wilber Carlos dos. A evolução do constitucionalismo no brasil e a atuação contemporânea dos tribunais de contas. Revista Eletrônica Direito e Política, Programa de PósGraduação Stricto Sensu em Ciência Jurídica da UNIVALI, Itajaí, v.10, n.3, 20 quadrimestre de 2015. Disponível em: www.univali.br/direitoepolitica - ISSN 1980-7791.

Subsumido ao constitucionalismo brasileiro, o controle externo da atividade administrativa do Estado, o que já era tema aventado por Aristóteles ${ }^{3}$ desde a Idade Antiga, surge em 1891, sob postulado constitucional, as Cortes de Contas, para exercerem, imparcialmente, a competência que lhe foi reservada; a experiência prática de tal controle apresentou resultados tão profícuos que, na atualidade, não é correto afirmar a sobrevivência do constitucionalismo brasileiro, se forem suprimidas as competências das Cortes de Contas, dada à sensível atuação, com notórios ganhos sociais, no controle geral da correta e inequívoca aplicação dos recursos públicos.

Buscar-se-á, nos tópicos subsequentes, demonstrar, ainda que sinteticamente, a evolução do Constitucionalismo, em especial o Constitucionalismo brasileiro, para trazer ao centro da discussão os Tribunais de Contas brasileiros, pontuando-se os eventos históricos de relevo que precederam a sua criação, para ao depois, descortinar suas atribuições e âmbito de competência atuacional, na contemporaneidade, como Órgão de Controle Externo, indispensável à sindicância dos atos da Administração Pública, com missão constitucional de guardião da res publica e fiscal dos parcos recursos públicos, tendo como destinatário final de suas ações, a sociedade, maior interessada em sua atividade fim.

\section{VERTENTES HISTÓRICAS DO CONSTITUCIONALISMO}

Para penetrarmos na categoria ${ }^{4}$ do constitucionalismo, convém esclarecer, inicialmente que não obstante o presente trabalho não ter a pretensão de exaurir o instituto em testilha, a pesquisa empreendida parte da sua concepção em

\footnotetext{
3 Referido pensador, já em remotos tempos, mas com reflexos na contemporaneidade, difundia a ideia de controle dos dinheiros públicos ao afirmar que "o exame das contas e a escolha das magistraturas constituem o maior de todos os poderes [...] enquanto que para administrar os dinheiros públicos, comandar os exércitos e exercer as magistraturas mais importantes, é preciso um sentimento elevado". ARISTÓTELES. A política. Tradução de Nestor Silveira. São Paulo: Folha de S. Paulo, 2010. p. 98-99.

4 Categoria, neste trabalho, compreendida na acepção trazida pelo professor PASOLD que a define como "palavra ou expressão estratégica à elaboração e/ou à expressão de uma idéia". PASOLD, Cesar Luiz. Metodologia da Pesquisa Jurídica: teoria e prática. 12 ed. São Paulo: Conceito Editorial, 2011. p.25
} 
SANTOS COIMBRA, Wilber Carlos dos. A evolução do constitucionalismo no brasil e a atuação contemporânea dos tribunais de contas. Revista Eletrônica Direito e Política, Programa de PósGraduação Stricto Sensu em Ciência Jurídica da UNIVALI, Itajaí, v.10, n.3, 20 quadrimestre de 2015. Disponível em: www.univali.br/direitoepolitica - ISSN 1980-7791.

sentido jurídico-político, evidenciada pela limitação dos poderes estatais e a garantia de direitos fundamentais, oriunda de remota luta do homem político pela restrição do poder.

Em rápida passagem pela Idade Antiga ${ }^{5}$, marcada pela ausência de Constituições rígidas e escritas, é possível visualizar, com segurança, embriões do Constitucionalismo em referida época, pela análise das missivas que prediziam princípios, costumes e tradições, norteadores da vida em sociedade, tal como no Egito, Babilônia, Roma, Grécia e tantas outras, que embora desprovidos de um Poder Constituinte, eram dotados de força normativa, ou como prefere Jacques:

Eram mais instituições que constituições, documentos escritos, códigos políticos. Não escritos, consuetudinários, e, por ato de modificação. Não se conheciam, ainda, o 'poder constituinte', de onde emanam as Constituições escritas, mas tão-só o 'poder legiferante ordinário'. ${ }^{6}$

Com raízes históricas que remontam à Antiguidade Clássica7, como acima demonstrado, somente após os feitos revolucionários americanos e franceses este, especificamente, com o fim dos regimes absolutistas - é que o Constitucionalismo Moderno ganhou parametrização mais robusta, atrelada às Constituições dos Estados Unidos da América, datada de 1787, e da França, de 1791, pós Revolução Francesa, passando a significar "em essência, limitação do poder e supremacia da lei" ${ }^{\prime 8}$, ou como já prelecionado por Canotilho em sua vasta contribuição sobre o tema "Constitucionalismo é a teoria (ou ideologia) que

5 Karl Loewenstein identificou no chamado Constitucionalismo da Antiguidade limitações, extraídas das escrituras, ao poder dos profetas do povo Hebreu - Estado Teocrático - e mais tarde, nas Cidades- Estados gregas, a identificação de um poder político "com plena identidade entre governantes e governados, no qual o poder político está igualmente distribuído entre todos os cidadãos ativos" LOEWENSTEIN, Karl. Teoría de la Constitución. Tradução de Alfredo Gallego Anabitarte. 2 ed. Barcelona: Ariel, 1970. p. 154-155.

6 JACQUES, Paulino. Curso de Direito Constitucional, 5a ed., Rio de Janeiro: Forense, 1957. p. 17.

7 É possível identificarmos nesse período, processos não aperfeiçoados que nos remetem a noções preliminares de Estado, marcados pela ausência de Constituições rígidas e escritas, mas racionada em vários eventos históricos que fizeram erigir o Direito Constitucional.

8 BARROSO, Luís Roberto. Curso de Direito Constitucional Contemporâneo: os conceitos fundamentais e a construção do novo modelo. 4. ed. São Paulo: Saraiva, 2013, p. 27. 
SANTOS COIMBRA, Wilber Carlos dos. A evolução do constitucionalismo no brasil e a atuação contemporânea dos tribunais de contas. Revista Eletrônica Direito e Política, Programa de PósGraduação Stricto Sensu em Ciência Jurídica da UNIVALI, Itajaí, v.10, n.3, $2^{\circ}$ quadrimestre de 2015. Disponível em: www.univali.br/direitoepolitica - ISSN 1980-7791.

ergue o princípio do governo limitado indispensável à garantia dos direitos em dimensão estruturante da organização político-social de uma comunidade" ${ }^{\prime 9}$

Pecces-Barba também reconhece que foi nas reflexões trazidas pelo modelo inglês e francês sobre a organização do Estado, que o constitucionalismo surgiu e cristalizou, inclusive, a primeira geração de direitos fundamentais:

Cuando la mentalidad del mundo moderno y la reflexión sobre la organización del poder, frente al Estado absoluto que producirá el primer constitucionalismo - alcance éxito social, estaremos em los albores del Estado liberal y em los primeiros modelos cristalizados em la historia de los derechos fundamentales, es decir, de uma moralidade recibida por el Derecho positivo. Desde el siglo XVII se podrá hablar de modelo inglês y desde el XVIII de modelos americano y francês. ${ }^{10}$

Das ideias intelectuais gestadas na efervescência das revoluções liberais verdadeiro contraponto ao poder centralizador e absolutista dos reis monarquistas - surgiu o Estado Liberal e com ele a sujeição ao comando da lei; a Constituição, no constitucionalismo moderno (clássico ou liberal), porquanto, nasce com função díade: aparelhar estruturalmente o Estado e limitá-lo, declarando e garantindo direitos.

De se perceber que as raízes do constitucionalismo estão relacionadas ao surgimento e evolução do Estado que - do governo único da Antiguidade, do regime feudal e centralizador de riquezas da Idade Média, dos poderes ilimitados do rei no regime absolutista da Idade Moderna, ao Estado Liberal e demais formas - comprovam no Poder Constituinte expressão política legítima e jurídica, concretizando a constitucionalização do Estado, a respeito da matéria aquilatada o professor Cruz pontua que:

\footnotetext{
9 CANOTILHO, J. J. Direito constitucional e teoria da constituição 7 ed. Coimbra: Edições Almedina. 2003. p. 51-52.

10 PECCES-BARBA, Gregorio. La diacronía del fundamento y del concepto de los Derechos: el tempo de la historia. In: Curso de Derechos Fundamentales: teoria general. Madrid: Universidad Carlos III de Madrid, 1995, p. 146.
} 
SANTOS COIMBRA, Wilber Carlos dos. A evolução do constitucionalismo no brasil e a atuação contemporânea dos tribunais de contas. Revista Eletrônica Direito e Política, Programa de PósGraduação Stricto Sensu em Ciência Jurídica da UNIVALI, Itajaí, v.10, n.3, $2^{\circ}$ quadrimestre de 2015. Disponível em: www.univali.br/direitoepolitica - ISSN 1980-7791.

A constitucionalização do Estado foi a principal via de atuação dos adeptos das diversas ideologias concebidas pelas vias racionais que se tornaram frequentes, principalmente após a Independência Norte-Americana, em 1779, e após a Revolução Francesa, de 1789. Foi com as Assembléias Constituintes ou a partir do exercício do Poder Constituinte, nas suas diversas formas de manifestação, que se deu a "ideologização" dos ordenamentos jurídicos estatais. ${ }^{11}$

Da vasta literatura autorizada podemos inferir, com segurança, que o legado deixado pelo constitucionalismo moderno consiste na afirmação de um Estado de Direito, de um Poder Constituinte Originário, na positivação de direitos e garantia da dignidade humana, entre outros; nesse sentido, na conjuntura atual do Constitucionalismo Contemporâneo e na perspectiva globalizada de progresso humano, não se afigura possível, ao que tudo revela, a prevalência de direitos individuais, coletivos e difusos sem a existência de uma constituição.

Na sequência compreensiva dos processos de evolução do constitucionalismo, há que se registrar brevemente, a gestação do constitucionalismo contemporâneo nos interstícios do século XIX e XX, balizado pela forte insurgência em face do capitalismo e pela busca de proteção aos direitos sociais e em permanente processo de construção de suas vertentes axiológicas, inseminadas pelos constantes processos de mudança oriundos da dinamicidade e anseios da vida social, política e econômica ou mesmo pela vinculação a um constitucionalismo globalizado que busca a difusão dos direitos humanos com o escopo de que todos os povos, de todas as nações, reconheçam-no como universal, tal qual defendido por Tavares. ${ }^{12}$, ainda que com carga um tanto utópica.

Numa primeira acepção, parece restar evidenciada a impossibilidade de se cogitar a garantia de direitos fundamentais sem a existência de uma constituição e sem a limitação do poder estatal. A esse respeito, Ferrajoli, ao debater a matéria identifica na Constituição o limite material e o argumento da democracia

${ }^{11}$ CRUZ, Paulo Márcio. Política, Poder, Ideologia e Estado Contemporâneo. 3. ed. 1a. tir. Curitiba: Juruá, 2003. p. 58.

12 TAVAReS, André Ramos. Curso de Direito Constitucional. 10. ed. São Paulo: Saraiva, 2012. p.38 
SANTOS COIMBRA, Wilber Carlos dos. A evolução do constitucionalismo no brasil e a atuação contemporânea dos tribunais de contas. Revista Eletrônica Direito e Política, Programa de PósGraduação Stricto Sensu em Ciência Jurídica da UNIVALI, Itajaí, v.10, n.3, $2^{\circ}$ quadrimestre de 2015. Disponível em: www.univali.br/direitoepolitica - ISSN 1980-7791.

substancial, anota que, tanto a estrutura do direito com a natureza da democracia são posteriores a derrota dos regimes totalitaristas presentes no nazismo e facismo, concluindo que as sociedades em que não há separação de poderes e nem garantia de direitos também não possuem Constituição:

Es entonces, en aquells anos cruciales, cuando nace el actual paradigma de la democracia constitucional. En las circunstancias culturales y políticas en las que nace el constitucionalismo actual -Ia Carta de las Naciones Unidas de 1945, la Declaración universal de los derechos humanos de 1948, la Constitución italiana de 1948, la Ley Fundamental de la República Federal Alemana de 1948- se compreende que el consenso de masas sobre el cual estaban fundadas las dictaduras fascistas, aunque fuera mayoritario, no puede ser ya la única fuente de legitimación del poder. ${ }^{13}$

Na atualidade, em especial após os marcos históricos do segundo pós-guerra, o debate Constitucionalista não mais se debruça sobre a preliminar ideia de limitação do poder político e avança para afastar o caráter meramente paradigmático do texto constitucional com o escopo de validar, no mundo fático, cada vez mais, a efetiva garantia dos direitos fundamentais, já positivados pelo constitucionalismo secular. O referido movimento, denominado de neoconstitucionalismo ou novo constitucionalismo, defende a necessidade de se empregar nova roupagem - por meio da hermenêutica e princípios constitucionais - ao texto da Lei Fundamental. Autores como Ferrajoli, Pisarello ${ }^{14}$, Pazzolo ${ }^{15}$, Sanchís ${ }^{16}$ - ainda que nenhum deles se declare neoconstitucionalistas e que suas teorias guarde qualquer heterogeneidade - são defensores do prefalado movimento que parece inumar, de forma definitiva, o Estado de Direito para ceder vez ao Estado Democrático de Direito.

\footnotetext{
13 FERRAJOLI, Luigi. Democracia constitucional y Derechos Fundamentales. In: Democracia

y garantismo. Tradução de Perfecto A. Ibáñes, et al. Madrid: Trotta, 2008. p. 28

14 PISARELLO, Gerardo. Los derechos sociales y sus garantias: elementos para uma reconstrucción. Madrid, 1995.

15 POZZOLO, Susanna. Neoconstitucionalismo y Especificidad de la Interpretación Constitucional, in Doxa: Cuadernos del filosia del derecho. Espanha: Doxa 21-II, 1998.

16 SANCHÍS, Luis Pietro. La teoria del Derecho em tiempos de constitucionalismo. In: CARBONELL, Miguel (Ed.). Neoconstitucionalismo(s). Madrid: Trotta, 2003.
} 
SANTOS COIMBRA, Wilber Carlos dos. A evolução do constitucionalismo no brasil e a atuação contemporânea dos tribunais de contas. Revista Eletrônica Direito e Política, Programa de PósGraduação Stricto Sensu em Ciência Jurídica da UNIVALI, Itajaí, v.10, n.3, $2^{\circ}$ quadrimestre de 2015. Disponível em: www.univali.br/direitoepolitica - ISSN 1980-7791.

Após traçar breves considerações acerca da origem do constitucionalismo ao longo da idade antiga até a idade contemporânea, avançamos, adiante, para traçar o contexto histórico-político no qual evoluiu o constitucionalismo brasileiro e a sua influência na formação dos Tribunais de Contas brasileiros.

\section{O CONSTITUCIONALISMO BRASILEIRO}

Os caminhos e processos do Constitucionalismo brasileiro, até a atual Constituição da República Federativa Brasileira de 1988, perpassam por dois marcos distintos: o Brasil Monárquico e o Republicano, totalizando oito constituições; com o advento da proclamação da independência do Brasil emerge a premente necessidade de se constituir uma constituição rígida, que proclame a unidade nacional e organize Estado em torno de um poder centralizador, estruturante do espaço político e jurídico da nação brasileira.

$\mathrm{Na}$ Monarquia imperial brasileira o constitucionalismo foi infundido pelas Constituições da França e Inglaterra, a Carta Política de 1824, pós independência, foi concebida indiscutivelmente à luz dos ideais liberais, alicerçada por uma multiplicidade de vertentes teóricas, abandonou a clássica divisão tripartida de poderes ideada por Montesquieu para acrescer a sua estrutura o Poder Moderador ${ }^{17}$, impôs, assim, uma modelagem liberal ao Estado ao tentar conciliar os princípios vigentes do liberalismo à conjuntura sócioeconômica-política de um Estado monárquico recentemente independente,

\footnotetext{
17 Henri-Benjamin Constant de Rebeque, político e intelectual do liberalismo do século XIX, idealizador da teoria do Poder Moderador, influenciou consideravelmente o Estado Imperial brasileiro com suas ideias liberais ao asseverar que para se garantir o equilíbrio necessário ao funcionamento harmonioso dos poderes legislativo, executivo e judiciário, faz-se necessário um quarto poder, dotado de neutralidade e capacidade de intervenção, como conferido a um árbitro, quando preciso fosse; o Brasil, nessa linha, deu vida a figura do 'monarca constitucional' que, em tese, regia o sistema político com margem de distância dos demais poderes. VIEIRA, José Ribas. Introdução ao pensamento de Benjamin Constant. In: REBECQUE, Henri Benjamin Constant de. Princípios políticos constitucionais. Tradução: Maria do Céu Carvalho. Rio de Janeiro: Liber Juris, 1989.
} 
SANTOS COIMBRA, Wilber Carlos dos. A evolução do constitucionalismo no brasil e a atuação contemporânea dos tribunais de contas. Revista Eletrônica Direito e Política, Programa de PósGraduação Stricto Sensu em Ciência Jurídica da UNIVALI, Itajaí, v.10, n.3, $2^{\circ}$ quadrimestre de 2015. Disponível em: www.univali.br/direitoepolitica - ISSN 1980-7791.

fincado em uma sociedade escravocrata, nos postulados doutrinários de Bonavides $^{18}$ :

A monarquia foi, não obstante, um longo passo para a estréia formal definitiva de um Estado Liberal, vinculado, todavia, a uma sociedade escravocrata, aspecto que nunca se deve perder de vista no exame das instituições imperiais.

Em brevíssima síntese, a conjugação de esforços resultante na outorga da Carta Constitucional de 1824 - não obstante seu texto declarar a igualdade perante a lei, mas no mundo concreto revelar-se escravocrata e conservadora, ou como identificado por Bastos ${ }^{19}$, "bastante original em sua matéria, mas apresenta a distinção entre a Constituição formal e a Constituição material" - logrou êxito ao garantir a estabilidade necessária à concretização do regime monárquico, com ampla anuência da elite dominante, positivando alguns direitos individuais que teriam significativa irradiação nas demais constituições subsequentes.

O período republicano, apatacado de novo contexto político, culminou com a elaboração da Constituição de 1891, arquitetada pelos militares e elite agrária, sem inquietação em promover mudanças na economia do país, mas firme em romper com o legado imperial, compendiou juridicamente o regime republicado fazendo sucumbir as instituições políticas do império, promovendo a separação do Estado da Igreja e instituindo o presidencialismo como forma de governo.

A primeira Constituição Republicana merece registro, porque manteve todos os direitos presentes na Constituição Imperial e ampliou este rol inserindo o voto universal e aberto para os homens que fossem alfabetizados e maiores de 21 anos.

Nos primórdios do Brasil República, com inspiração da Constituição americana de 1787, o Poder Moderador, central no Império, como dito alhures, foi extinto para

\footnotetext{
${ }^{18}$ BONAVIDES, Paulo. Curso de Direito Constitucional. 23. ed. São Paulo: Malheiros, 2008. p. 363

${ }^{19}$ BASTOS, Celso Ribeiro. Curso de direito constitucional. 20. ed. atual. São Paulo: Saraiva, 1999. p. 46.
} 
SANTOS COIMBRA, Wilber Carlos dos. A evolução do constitucionalismo no brasil e a atuação contemporânea dos tribunais de contas. Revista Eletrônica Direito e Política, Programa de PósGraduação Stricto Sensu em Ciência Jurídica da UNIVALI, Itajaí, v.10, n.3, $2^{\circ}$ quadrimestre de 2015. Disponível em: www.univali.br/direitoepolitica - ISSN 1980-7791.

conceder espaço à teoria da tripartição de Poderes de Montesquieu, desta vez sem remendos, conforme assinalado por da Silva 20 "o sistema constitucional implantado enfraquecera o poder central e reacendera os poderes regionais e locais, adormecidos sob o guante do mecanismo unitário e centralizado do império", emergenciando a implantação do federalismo como resposta aos anseios da oligarquia dominante, presente nas incursões do cenário sóciopolítico-econômico da república.

A Carta Política de 1934, oriunda da Revolução constitucionalista de 1932 que pressionou o governo provisório de Getúlio Vargas a adotar medidas pungentes que atendessem as demandas surgidas desde a queda do regime oligárquico, consolidou ambições do Constitucionalismo Moderno, fortaleceu a independência, a repartição de competência entre os poderes do Estado e robustas mudanças no sistema de controle de constitucionalidade, além de consubstanciar um leque maior de direitos fundamentais, como o sufrágio universal (desta vez sem discriminação quanto ao sexo), proteção social ao trabalho, salário mínimo, entre outras mudanças que, não obstante sua inserção no texto constitucional, permaneceram factualmente inócuos, como observa Cunha:

\begin{abstract}
A realidade constitucional deste período determinou-se pelo estiolar das liberdades (com muitas perseguições a intelectuais, nomeadamente) e por alguma demofilia, traduzida em muitas medidas sociais. $\mathrm{Na}$ verdade, a Constituição nunca terá sido verdadeiramente normativa, mas semântica. ${ }^{21}$
\end{abstract}

A grande conquista herdada pela Constituição de 1934, não obstante o rápido lampejo de vigência da Constituição de 1934, apenas três anos, e da sua

\footnotetext{
${ }^{20}$ SILVA, Jóse Afondo da. Curso de Direito Constitucional Positivo. 9. ed. São Paulo: Malheiros Editores, 1993, p. 73.

${ }^{21}$ CUNHA, Paulo Ferreira da. Do Constitucionalismo Brasileiro: uma introdução histórica (18241998). Historia Constitucional, núm. 8, septiembre-, 2007, pp. 263-271. Disponível em <http://biblioteca.universia.net/html_bura/ficha/params/id/29142206.html>. Disponível em 10 de julho de. 2015.
} 
SANTOS COIMBRA, Wilber Carlos dos. A evolução do constitucionalismo no brasil e a atuação contemporânea dos tribunais de contas. Revista Eletrônica Direito e Política, Programa de PósGraduação Stricto Sensu em Ciência Jurídica da UNIVALI, Itajaí, v.10, n.3, 20 quadrimestre de 2015. Disponível em: www.univali.br/direitoepolitica - ISSN 1980-7791.

ineficiência material, esta Constituição deixou formalizada vultosas conquistas sociais a serem aperfeiçoados pelo Estado Social ${ }^{22}$.

A história do constitucionalismo brasileiro, com o Diploma Constitucional de 1937 - inspirada na constituição polonesa de 1935, fruto do golpe Getulista (Revolução de 1930) que decretou o Estado Novo - aufere visível anacronismo ao constitucionalismo Moderno quanto à repartição de competência e independência dos Poderes. A nova ordem conformou no plano jurídico e político um regime centralizado, firme em fortalecer o Poder Executivo federal frente aos demais poderes e com o escopo de "conciliar os interesses do trabalhismo incipiente com as tendências conservadoras do capitalismo"23, na prática, desconheceu a autonomia dos entes da federação e legislou por meio de Decretos-Lei.

A Constituição Federativa de 1946, como o desiderato de tornar perene o constitucionalismo moderno, devolveu o princípio da separação e harmonia dos poderes e emprestou novo amoldamento à ação direta de inconstitucionalidade retomando a democracia social presente na Constituição de 1934, revitalizando institutos jurídicos como ação popular, mandado de segurança, direito à liberdade, à propriedade, à individualização da pena, a proibição da pena de morte, entre outros, manteve, portanto, importantes direitos garantidos na Carta outorgada em 1934, buscando conformar princípios de liberdade e justiça social e esquadrinhando a redução dos abusos econômicos, mais uma vez, "na prática das relações sociais, grande parte desses direitos não foram incorporados ao cotidiano da maioria dos brasileiros. Nessa época, como em outros períodos, permaneceu no Brasil uma considerável distância entre o país legal e o país

22 Na acepção de Cruz, Estado Social é compreendido como Estado Contemporâneo Democrático ou Estado de Bem-Estar ou ainda Estado Social-Democrata, "produto da reforma do modelo clássico de Estado Liberal (...) caracteriza-se pela união da tradicional garantia de liberdades individuais como o reconhecimento, como direitos coletivos, de certos serviços sociais que o Estado providencia pela intervenção", CRUZ, Paulo Márcio. Política, Poder, Ideologia e Estado Contemporâneo. p. 163

23 FERreirA, Luís Pinto. Princípios Gerais do Direito Constitucional Moderno. 6. ed. São Paulo: Saraiva, v. 1, 1983. p. 73. 
SANTOS COIMBRA, Wilber Carlos dos. A evolução do constitucionalismo no brasil e a atuação contemporânea dos tribunais de contas. Revista Eletrônica Direito e Política, Programa de PósGraduação Stricto Sensu em Ciência Jurídica da UNIVALI, Itajaí, v.10, n.3, $2^{\circ}$ quadrimestre de 2015. Disponível em: www.univali.br/direitoepolitica - ISSN 1980-7791.

real $^{24}$, com poucos progressos materiais mas de insofismável avanço formal ao possibilitar o refinamento da expressão social do Estado brasileiro.

A Lei Maior de 1967, outorgada pelo Regime Militar brasileiro instituído pelo golpe militar de 1964, usurpou todos os poderes do Legislativo e conferiu extensos poderes ao Chefe do Executivo comprometendo, destarte, gravemente os ideais políticos do constitucionalismo moderno instaurando-se, nesse período, regime ditatorial conduzido por vários Atos Institucionais que restringiram liberdades públicas e suspenderam direitos e garantias constitucionais, anteriormente conquistados, não obstante, quanto ao sistema de controle de constitucionalidade, não tenha formalizado maiores mudanças.

Na Constituição Federal de 1988, ainda a irradiar seus efeitos nos dias atuais, deu notória prevalência aos fundamentos do constitucionalismo norte-americano e francês, visto que o constituinte fez nela inserir o garantismo da Constituição dos Estados Unidos de 1787, e as liberdades e separação de podres previstas na Constituição Francesa de 1791. Para o jurista Sarlet, corroborando com este entendimento, a Constituição brasileira de 1988 trouxe uma contribuição para o constitucionalismo mundial:

De qualquer modo, a despeito de seus aspectos menos virtuosos, a assim chamada "Constituição Cidadã" - a evolução subsequente o veio a demonstrar - consiste em texto constitucional sem precedentes na história do Brasil, seja quanto a sua amplitude, seja no que diz com o seu conteúdo, não sendo desapropriado afirmar que se trata também de um contributo (jurídico-político) brasileiro para o constitucionalismo mundial, seja em virtude da forte recepção das modernas tendências na esfera do direito constitucional, seja pelas particularidades do texto brasileiro. [...] No que diz com suas principais características, além do seu perfil analítico e casuístico, já referidos, a Constituição Federal de 1988 pode ser considerada como a mais democrática e avançada em nossa história constitucional, seja em virtude do seu processo de elaboração, seja em função da experiência acumulada em relação aos

${ }^{24}$ FAUSTO, Boris. História do Brasil. 12. ed. São Paulo: Editora da Universidade de São Paulo, 2004. p. 36. 
SANTOS COIMBRA, Wilber Carlos dos. A evolução do constitucionalismo no brasil e a atuação contemporânea dos tribunais de contas. Revista Eletrônica Direito e Política, Programa de PósGraduação Stricto Sensu em Ciência Jurídica da UNIVALI, Itajaí, v.10, n.3, $2^{\circ}$ quadrimestre de 2015. Disponível em: www.univali.br/direitoepolitica - ISSN 1980-7791.

acontecimentos constitucionais pretéritos, tendo contribuído em muito para assegurar a estabilidade institucional que tem sido experimentada desde então no Brasil. $^{25}$

Dessa maneira, parece coerente inferir que a atual Constituição brasileira traz em suas cláusulas aportes de notória contribuição ao constitucionalismo brasileiro fazendo emergir nova concepção do constitucionalismo contemporâneo, também cognominado de novo constitucionalismo ou neoconstitucionalismo, cuja doutrina irradia compreensão técnico-científica que promove a Constituição ao centro do sistema enquanto norma jurídica dotada de imperatividade e superioridade.

Seguindo nessa linha de desenvolvimento, passamos, agora, a desvendar a relação existente entre a atuação contemporânea dos Tribunais de Contas brasileiro e o processo de evolução do constitucionalismo.

\section{A CRIAÇÃO DOS TRIBUNAIS DE CONTAS COMO ELEMENTO DO CONSTITUCIONALISMO BRASILEIRO}

Abreviadas considerações históricas acerca da institucionalização dos Tribunais de Contas no Brasil merecem registro, antes de avançarmos a discussão, para destacar alguns marcos históricos relevantes que precederam sua criação.

A história do controle externo brasileiro perpassa a evolução do constitucionalismo no Brasil. A preocupação com o dinheiro púbico no País é anterior a sua independência e remonta ao período colonial; já em 1516, o Rei D. Manoel emitiu Regimento da Fazenda, no qual vinculava o registro de todos os contratos de arrecadação junto ao Rei, em claro controle administrativo dos contratos públicos vigentes, nesta quadra histórica o regime que vigorava era o das Capitanias Hereditárias (1534), depois substituído para o sistema de Governo-Geral (1549) que centralizava na figura do Governador a representação dos interesses da Coroa Portuguesa.

${ }^{25}$ FerreirA, Luís Pinto. Princípios Gerais do Direito Constitucional Moderno. p. 254-255. 
SANTOS COIMBRA, Wilber Carlos dos. A evolução do constitucionalismo no brasil e a atuação contemporânea dos tribunais de contas. Revista Eletrônica Direito e Política, Programa de PósGraduação Stricto Sensu em Ciência Jurídica da UNIVALI, Itajaí, v.10, n.3, 20 quadrimestre de 2015. Disponível em: www.univali.br/direitoepolitica - ISSN 1980-7791.

Ao Provedor-Mor, uma das figuras de auxílio ao Governador-Geral na organização do espaço colonial, concentrava a responsabilidade pela arrecadação de impostos e cuidava dos dispêndios financeiros legados pela administração do território.

Em 1680 e ainda sob o jugo da jurisdição de Portugal, foram criadas as Juntas das Fazendas das Capitanias e a Junta da Fazenda do Rio de Janeiro. As Juntas da Real Fazenda detinham o controle de quase todas as repartições fazendárias do Brasil e possuíam atribuições para arrecadar impostos, julgar processos e recursos fiscais, tomada de contas dos responsáveis por dinheiro e bens públicos ${ }^{26}$, entre outros.

É salutar registrar que no Brasil-colônia não havia real preocupação da Coroa Portuguesa em prevenir ou afastar fraudes ou, menos ainda, qualquer preocupação com os princípios da eficiência, posto que cogitado controle possuía cunho unicamente capitalista, com vistas a otimizar a rica e fecunda arrecadação que a colônia brasileira gerava.

Posteriormente, em 1808, com a vinda da Família Real para o Brasil, criou-se o Erário Régio ${ }^{27}$ e o Conselho da Fazenda ${ }^{28}$ - mas ainda sob o comando da Coroa Portuguesa - com o desiderato de sindicar a execução da despesa pública, mais tarde, o Erário Régio foi alçado a Tesouro pelas disposições expressas na Constituição Imperial de 1824, plasmando, então, o surgimento dos Tribunais de Contas.

26 MENDONÇA, Marcos Carneiro de. O Erário Régio no Brasil. Rio de Janeiro: Ministério da Justiça, 1968. p 58-147

27 O Erário Régio de Portugal, também chamado de Real Erário, Real Fazenda, Tesouro Público ou Tesouro Geral, criado no Brasil na administração de D. João VI por meio do Decreto de 11 de março de 1808, era uma instância de centralização da contabilidade do Reino. WEHLING, Arno. Administração portuguesa no Brasil, 1777-1808, Brasília, Funcep, 1986, p. 15 ss.

28 O Conselho da Fazenda foi estabelecido pelo mesmo documento jurídico que instituiu o Erário Régio e foi instalado com o objetivo de centralizar a administração dos rendimentos reais e tinha a finalidade de superintender o tráfico comercial e as armadas, recolher os créditos das riquezas ultramarinas e deliberar sobre as despesas de navegação e guerra. Sob sua dependência estavam a Casa dos Contos, a Casa da Índia, a Casa da Moeda, as alfândegas e os feitores que comerciavam a favor do monarca. HESPANHA, António Manuel. As vésperas do Leviathan: instituições e poder político, Portugal (século XVII). Coimbra: Almedina, 1994. p. 236 
SANTOS COIMBRA, Wilber Carlos dos. A evolução do constitucionalismo no brasil e a atuação contemporânea dos tribunais de contas. Revista Eletrônica Direito e Política, Programa de PósGraduação Stricto Sensu em Ciência Jurídica da UNIVALI, Itajaí, v.10, n.3, $2^{\circ}$ quadrimestre de 2015. Disponível em: www.univali.br/direitoepolitica - ISSN 1980-7791.

Nos subtópicos seguintes, a pretexto de melhor enfrentamento da temática central trabalhada, faz-se ligeira digressão histórica sobre os elementos primordiais que se perfilam como gênese do que se conhece hoje como Tribunal de Contas e sua história ao longo das Constituições brasileiras.

\subsection{Do Controle Externo no Brasil e o desdobramento de suas atribuições ao longo da evolução constitucional brasileira}

Como se sabe, porque perfila nos registros históricos, em 1822 ocorreu a Proclamação da Independência, e consequentemente a transformação do Erário Régio em Tesouro Nacional pela Constituição Imperial de 1824, disso sobreveio todas as consequências da libertação e transformação do território colonial brasileiro em país federativo: autonomia política, soberania da nação, recursos e contabilidade próprios. Instala-se, nesse panorama, premente necessidade de controle, para além da experiência vivenciada com a Coroa Portuguesa, com o erário real.

Deve-se a Felisberto Caldeira Brandt, Visconde de Barbacena e a José Inácio Borges o nascimento de uma Corte de Contas brasileira quando, em 1826, propuseram projeto de lei ao Senado do Império para sua criação, todavia, somente em 1890, por meio do Decreto $966-\mathrm{A}^{29}$, pela pena do então Ministro da Fazenda, Rui Barbosa, erigiu-se formalmente o primeiro Tribunal de Contas da União, mais tarde consagrado no art. 89 da Constituição Republicana de 1891, com forte influência dos modelos italiano, belga e francês ${ }^{30}$ e com competência para perscrutar as contas da receita antes destas serem prestadas ao Congresso Nacional; sua instalação, porém, só ocorreu em 17 de janeiro de 1893.

${ }^{29}$ BRASIL. Decreto n. ${ }^{\circ}$ 966-A, de 07 de novembro de 1890. Crêa um Tribunal de Contas para o exame, revisão e julgamento dos actos concernentes á receita e despeza da Republica. Coleção de Leis do Brasil - 1890, Página 3440 Vol. Fasc. XI (Publicação Original) Disponível em: http://www2.camara.leg.br/legin/fed/decret/1824-1899/decreto-966-a-7-novembro-1890553450-norma-pe.html. Acesso em: 05 julho de 2015.

30 GOMES, Ademar Martins Bento. A trajetória dos Tribunais de Contas: estudos sobre a evolução do controle externo da administração pública. Salvador: Tribunal de Contas do Estado da Bahia, 2002. p. 18. 
SANTOS COIMBRA, Wilber Carlos dos. A evolução do constitucionalismo no brasil e a atuação contemporânea dos tribunais de contas. Revista Eletrônica Direito e Política, Programa de PósGraduação Stricto Sensu em Ciência Jurídica da UNIVALI, Itajaí, v.10, n.3, $2^{\circ}$ quadrimestre de 2015. Disponível em: www.univali.br/direitoepolitica - ISSN 1980-7791.

Aguiar, Alburquerque e Medeiros ${ }^{31}$ chamam a atenção para o fato de que o Decreto de Rui Barbosa padecia de regulamentação, conforme fixado no art. 11 do próprio Decreto, tendo existência meramente formal, somente efetivamente consubstanciado em 1891, no texto da primeira Carta Política republicana, "vale, contudo, esclarecer que o Tribunal de Contas, que somente foi adjetivado com o termo "da União" na Constituição de 1967, já havia sido pensado desde o início da Era Imperial".

Rui Barbosa, ao idealizar um órgão público com a envergadura do Tribunal de Contas da União, já transparecia a influência trazida pelas novas concepções do constitucionalismo, na qual o Estado não devia contentar-se apenas em promover igualdade formal, mas sim o dever de efetivamente concretizar a igualdade social, como, de fato, albergado pela Constituição de 1891, nas lições de Branco:

\begin{abstract}
Supremacia do Parlamento e supremacia da lei eram aspectos de um mesmo fenômeno, hostil, por si mesmo, a ideia de um instrumento normativo superior ao parlamento e a lei. Comprometia-se, assim, a noção de constituição como instrumento de valor normativo eficaz, capaz de estabelecer parâmetros para aferição da validade jurídica dos atos dos poderes públicos. Tudo isso conduzia, também, a que tampouco se emprestasse maior relevância ao problema da modificação da Constituição por via institucional. ${ }^{32}$
\end{abstract}

Dessa sorte, o intento de criação de um Tribunal de Contas no Brasil surgiu por necessidade imperiosa de organização da administração geral do recémindependente Estado brasileiro, firme nesse propósito, por meio da Lei n. 657 de 04 de outubro de 1831, criou-se o Tribunal do Tesouro Público Nacional com a obrigação de:

\footnotetext{
${ }^{31}$ AGUIAR, Ubiratan Diniz de; ALBUQUERQUE, Marcio André Santos de; MEDEIROS, Paulo Henrique Ramos. A Administração Pública sob a Perspectiva do Controle Externo. $1^{a}$. reimp. Belo Horizonte:Fórum, 2011. p. 196

32 BRANCO, Paulo Gustavo Gonet. Curso de direito constitucional. 4.ed. São Paulo: Saraiva, 2009, p. 223.
} 
SANTOS COIMBRA, Wilber Carlos dos. A evolução do constitucionalismo no brasil e a atuação contemporânea dos tribunais de contas. Revista Eletrônica Direito e Política, Programa de PósGraduação Stricto Sensu em Ciência Jurídica da UNIVALI, Itajaí, v.10, n.3, $2^{\circ}$ quadrimestre de 2015. Disponível em: www.univali.br/direitoepolitica - ISSN 1980-7791.

Administrar a receita e a despesa pública, a contabilidade e os bens nacionais, receber a prestação de contas anuais de todas as repartições públicas, analisar os empréstimos e a legislação fazendária, inspecionar as repartições da fazenda, ainda que dependentes de outros Ministérios e demitir funcionários públicos considerados inidôneos e inabilitados à ocupação dos cargos. ${ }^{33}$

Cabe veicular no presente trabalho, para demonstração da incidência do constitucionalismo histórico no Brasil, que o novo Tribunal, originariamente, nasceu com competência para exame, revisão e julgamento de todas as operações relacionadas com a receita e a despesa da União, gradativamente, tal mister foi sendo ampliado à esfera estadual, conferindo sensível controle externo da Administração Pública, no ponto, como exposto por Gomes:

Os Estados que sempre puderam exercer os poderes que, implícita ou explicitamente, não lhes fossem vedados pela Constituição Federal, passaram, paulatinamente, a adotar para si o mesmo sistema de fiscalização financeira e orçamentária estabelecido para a União ${ }^{34}$.

Seguindo a evolução da matéria aquilatada nas constituições subsequentes ao Brasil pós-República, em busca de se demonstrar o desdobramento das atribuições das Cortes de Contas e sua evolução Constitucional, temos que a Constituição de 1934 registrou expressivo marco histórico na história de referidos Tribunais ao ampliar sua competência e enxertar em suas atribuições o julgamento das contas dos responsáveis por dinheiros ou bens públicos, 0 acompanhamento da execução do orçamento e o registro dos contratos de interesse da receita ou da despesa, assim como apresentar parecer prévio sobre as contas do Presidente da República para posterior encaminhamento ao Congresso Nacional. Regulou ainda, conforme a Lei n. 156 de 24 de dezembro de 1935, o funcionamento da instituição fixando em sete o número de julgadores de seu corpo colegiado. Nas palavras de Pontes de Miranda:

33 BRASIL. Lei n. 657 de 04 de outubro de 1831. Dá organização ao Tesouro Público Nacional e às Tesourarias das Províncias. Coleção das leis do Império do Brasil, Rio de Janeiro, parte 1, p. $103-127,1875$.

34 GOMES, Ademar Martins Bento. A trajetória dos Tribunais de Contas: estudos sobre a evolução do controle externo da administração pública. p. 18. 
SANTOS COIMBRA, Wilber Carlos dos. A evolução do constitucionalismo no brasil e a atuação contemporânea dos tribunais de contas. Revista Eletrônica Direito e Política, Programa de PósGraduação Stricto Sensu em Ciência Jurídica da UNIVALI, Itajaí, v.10, n.3, $2^{\circ}$ quadrimestre de 2015. Disponível em: www.univali.br/direitoepolitica - ISSN 1980-7791.

\begin{abstract}
A Constituição de 1934 considerou-o órgão de cooperação nas atividades governamentais. Ao antigo Tribunal de Contas - que a Constituição manteve (art.99: é mantido) - o texto de 1934 conferiu, assim, a mais, a atribuição de julgar as contas dos responsáveis por dinheiros ou bens públicos em toda a sua extensão. O acréscimo, em vez de o tornar órgão cooperador do Poder Executivo, acentuou o elemento judiciário que já ele tinha, inclusive pelo modo de composição e garantias de seus membros. ${ }^{35}$
\end{abstract}

A Carta de 1937, com exceção do parecer prévio sobre as contas presidenciais, manteve hígida, em seu texto constitucional, todas as demais competências e atribuições já existentes da Constituição de 1934, não merecendo, maiores ilações.

Foi, todavia, na Carta Maior de 1946, com a Lei n 830, de 23 de setembro de 1949, que o Tribunal de Contas alçou ao status de órgão auxiliar técnico do Poder Legislativo na fiscalização da administração financeira da União e reestruturou, mais uma vez, sua organização funcional fixando em nove seu número de ministros com encargo de julgar as contas dos administradores das entidades autárquicas e a legalidade das aposentadorias, reformas e pensões, além das incumbências já existentes na Constituição de 1934.

Em 1964, com a eclosão do golpe militar e a implantação do regime ditatorial no Brasil, registrou-se, materializado na Constituição de 1967, anacrônica e dramática diminuição dos poderes atribuído às Cortes de Contas em constituições precedentes. Mencionada Carta Política subtraiu do Tribunal o exame e o julgamento prévio dos atos e contratos geradores de despesas, o julgamento da legalidade de concessões de aposentadorias, reformas e pensões, remanescendo, apenas, competência para exercício do controle externo quanto à auditoria financeira e orçamentaria das contas do Legislativo, Executivo e Judiciário, com poder para apontar falhas e irregularidades que, caso não fossem regularizadas, deveriam ser representadas ao Congresso Nacional.

35 PONTES DE MIRANDA, Francisco Cavalcanti. Comentários à Constituição de 1967: com a EC n.01, de 1969. 2. ed. São Paulo: Revista dos Tribunais, 1970, t.III, p.248. 
SANTOS COIMBRA, Wilber Carlos dos. A evolução do constitucionalismo no brasil e a atuação contemporânea dos tribunais de contas. Revista Eletrônica Direito e Política, Programa de PósGraduação Stricto Sensu em Ciência Jurídica da UNIVALI, Itajaí, v.10, n.3, $2^{\circ}$ quadrimestre de 2015. Disponível em: www.univali.br/direitoepolitica - ISSN 1980-7791.

Com o advento da Lei n. 6.223 de 14 de julho de 1975, nova alteração tocou sobre as competências do Tribunal de Contas da União, desta vez para alargar sua atuação e permitir a fiscalização orçamentária das entidades da administração indireta, como as sociedades de economia, as empresas públicas e as fundações - à época, referidas contas eram analisadas por servidores do Poder Executivo.

Contemporaneamente, com a promulgação da Constituição dita 'cidadã' de 1988, houve diametral ampliação dos poderes conferidos ao Tribunal de Contas da União, com substrato constitucional, agora sim, para exercer a fiscalização contábil, financeira, orçamentária, operacional e patrimonial da União e das entidades da administração direta e indireta, quanto à legalidade, à legitimidade, e à economicidade e à fiscalização da aplicação das subvenções e da renúncia de receitas de qualquer pessoa física ou jurídica, pública ou privada, que utilize, arrecade, guarde, gerencie ou administre dinheiros, bens e valores públicos ou pelos quais a União responda, ou que, em nome desta, assuma obrigações de natureza pecuniária, devendo digitadas entidades prestar, obrigatoriamente, contas ao TCU, na forma disposta nos arts. 70 e 72 da CRFB/88. ${ }^{36}$

Como evidenciado, na atual Constituição Federal de 1988, quis o Poder Constituinte Originário trazer elementos do constitucionalismo contemporâneo à competência e atribuições dos Tribunais de Contas; nitidamente, sem embargos, as perspectivas constitucionais inseridas no Diploma Político Maior estrutura a atuação das Cortes de Contas, nos limites das nuances do constitucionalismo moderno e contemporâneo, uma vez que são Os Tribunais de Contas responsáveis pela fiscalização contábil, financeira, orçamentária, operacional e patrimonial da atividade Administrativa do Estado brasileiro.

36 BRASIL. Constituição da República Federativa do Brasil de 1988. Disponível em: http://www.planalto.gov.br/ccivil_03/constituicao/constituicao.htm. Acesso em: 25 de julho de 2015 
SANTOS COIMBRA, Wilber Carlos dos. A evolução do constitucionalismo no brasil e a atuação contemporânea dos tribunais de contas. Revista Eletrônica Direito e Política, Programa de PósGraduação Stricto Sensu em Ciência Jurídica da UNIVALI, Itajaí, v.10, n.3, $2^{\circ}$ quadrimestre de 2015. Disponível em: www.univali.br/direitoepolitica - ISSN 1980-7791.

Disso decorre, sem refutação aparente, que as áreas de atuação dos Tribunais de Contas englobam todas as facetas do Estado em que se emprega dinheiros públicos, do que se extrai que as Cortes de Contas, como órgãos superiores vinculados, mas não subordinados, ao Poder Legislativo, subsumem-se aos ditames do constitucionalismo, visto que uma de suas metas sociais é o equilíbrio entre os Poderes, na repartição de competência e a transparência da atuação estatal, cabe registrar, porque de relevo, que a estrutura nevrálgica, legada aos Tribunais de Contas com a Constituição de 1988, apartou-se grandemente da composição assumida pela Corte de Contas Portuguesa, ponto de partida e referência de toda a história do controle externo brasileiro.

Fernandes ${ }^{37}$, discorrendo acerca do Tribunal de Contas Português, chama a atenção e assevera que este é "definido pela Constituição de 1976 como um tribunal financeiro integrado no aparelho do judiciário, ao lado de outros tribunais superiores" complementar, portanto, do Poder Judiciário, incumbido de jurisdição financeira, bem diferente dos rumos trilhados no Brasil, como demonstrado em linhas precedentes e de importante consignação no presente trabalho, sob a ótica da percepção histórico-evolutiva do constitucionalismo brasileiro.

\section{DA ATUAÇÃO CONTEMPORÂNEA DOS TRIBUNAIS DE CONTAS}

Os Tribunais de Contas têm, como afirmado em linhas pretéritas, função essencial para realizar a fiscalização contábil, financeira, orçamentária, operacional e patrimonial dos entes federativos, da Administração Pública direta e indireta. As empresas públicas e sociedades de economia mista também estão sujeitas à fiscalização dos Tribunais de Contas, nos moldes fixados no inciso II do art. 71 da CRFB/88.

Art. 71. O controle externo, a cargo do Congresso Nacional, será exercido com o auxílio do Tribunal de Contas da União, ao qual compete:

$(\ldots)$

37 FERNANDES, Jorge Ulisses Jacoby. Tribunais de Contas do Brasil: jurisdição e competência. 2. Ed. 1. Reimpressão. Belo Horizone: Fórum, 2008, p. 163. 
SANTOS COIMBRA, Wilber Carlos dos. A evolução do constitucionalismo no brasil e a atuação contemporânea dos tribunais de contas. Revista Eletrônica Direito e Política, Programa de PósGraduação Stricto Sensu em Ciência Jurídica da UNIVALI, Itajaí, v.10, n.3, $2^{\circ}$ quadrimestre de 2015. Disponível em: www.univali.br/direitoepolitica - ISSN 1980-7791.

II - julgar as contas dos administradores e demais responsáveis por dinheiros, bens e valores públicos da administração direta e indireta, incluídas as fundações e sociedades instituídas e mantidas pelo Poder Público federal, e as contas daqueles que derem causa a perda, extravio ou outra irregularidade de que resulte prejuízo ao erário público; 38

A competência fiscalizadora dos Tribunais de Contas, destarte, refere-se à realização de auditorias e inspeções em entidades e órgãos da Administração Pública, fiscalizam também procedimentos licitatórios, podendo expedir medidas cautelares ou tutelas de urgência para evitar futura lesão ao erário e garantir o cumprimento de suas decisões. Possuem ainda competência judicante que é a de realizar o julgamento das contas anuais de gestão dos administradores e demais responsáveis pelo erário na Administração Pública.

Destaca-se, porque de relevo, a competência sancionatória dos Tribunais de Contas no que se refere à aplicação de sanções pecuniárias por ilegalidades de contas e despesas, bem como pela violação formal de lei e atos normativos específicos, sem repercussão danosa ao erário; suas decisões sancionatórias têm eficácia de título executivo, e, se transitadas formalmente em julgado, podem ser executadas como direito líquido, certo e exigível.

Adotados pelo constitucionalismo brasileiro, os Tribunais de Contas, na atual ordem constitucional, isto é, com a manifestação política do Constituinte de 1988, passaram a ser protagonistas de grande contribuição relativa ao controle externo da atividade Administrativa do Estado; matizes que decorrem da competência dos mencionados órgãos de controle orientam que nenhum órgão público, ou entidade privada, que receba e utilize recursos públicos, isenta-se de fiscalização das Cortes de Contas; noutras palavras, os Tribunais de Contas são, intransigentemente, pró-erário, uma vez que possuem iniciativa própria para iniciar quaisquer espécies de fiscalização com vistas a identificar a correta aplicação dos recursos públicos, quer seja diretamente, por órgãos públicos,

38 BRASIL. Constituição da República Federativa do Brasil de 1988. Disponível em: http://www.planalto.gov.br/ccivil_03/constituicao/constituicao.htm. Acesso em: 25 de julho de 2015. 
SANTOS COIMBRA, Wilber Carlos dos. A evolução do constitucionalismo no brasil e a atuação contemporânea dos tribunais de contas. Revista Eletrônica Direito e Política, Programa de PósGraduação Stricto Sensu em Ciência Jurídica da UNIVALI, Itajaí, v.10, n.3, 20 quadrimestre de 2015. Disponível em: www.univali.br/direitoepolitica - ISSN 1980-7791.

quer, por meio de subvenções aportadas a entidades de caráter público, ou privada, sem fins lucrativos.

Assim, desde a primeira Carta Política promulgada, no Brasil, o constitucionalismo por aqui adotado, percebe-se notável evolução na sua concretização, tornando-se, contemporaneamente, numa espécie de 'Poder Estatal de Controle Externo' - sem sê-lo na topografia orgânico-constitucional adotada -, qualificando-se como órgão autônomo, dotado de autogoverno e imprescindível para o fim a que fora proposto.

De se vê, as manifestações institucionais-concretas do Parlamento Brasileiro, consistente na elaboração de normas deônticas, fazendo-se ouvir pelo Controle Social, editando legislação que torne transparentemente o emprego dos dinheiros públicos, assegura prevalência aos Tribunais de Contas para fazer concretizar a cogência das mencionadas normas, uma vez que toca aos Tribunais de Contas velar e zelar pela prevalência do interesse público.

Todos, em especial os diplomas legislativos que remetem à Lei de Improbidade Administrativa ${ }^{39}$, a Lei do Portal da Transparência ${ }^{40}$ e a Lei de acesso público a informações estatais ${ }^{41}$, configuram-se em rígidos aportes ao controle social na medida que, por intermédio do instituto da transparência administrativa, põem

39 BRASIL. Lei no $\mathbf{8 . 4 2 9}$ de 02 de junho de 1992. Dispõe sobre as sanções aplicáveis aos agentes públicos nos casos de enriquecimento ilícito no exercício de mandato, cargo, emprego ou função na administração pública direta, indireta ou fundacional e dá outras providências. Diário Oficial da União, Brasília, DF, ano 130, n. 105, 03 de junho de 1992. Seção I, p.1. Disponível em: http://www.planalto.gov.br/ccivil_03/LEIS/L8429.htm. Acesso em: 31 de julho de 2015.

40 BRASIL. Lei Complementar n. 131, de 27 de maio de 2009. Acrescenta dispositivos à Lei Complementar $n^{\circ} 101$, de 4 de maio de 2000, que estabelece normas de finanças públicas voltadas para a responsabilidade na gestão fiscal e dá outras providências, a fim de determinar a disponibilização, em tempo real, de informações pormenorizadas sobre a execução orçamentária e financeira da União, dos Estados, do Distrito Federal e dos Municípios. Diário Oficial da União, Brasília/DF, p. 2, 28 de maio de 2009. Disponível em: http://www.planalto.gov.br/ccivil_03/leis/LCP/Lcp131.htm . Acesso em: 31 de julho de 2015.

41 BRASIL. Lei n.12.527, de 18 de novembro de 2011. Regula o acesso a informações previsto no inciso XXXIII do artigo 50, no inciso II do \& $3^{\circ}$ do art. 37 e no \& $2^{\circ}$ do art.216 da Constituição Federal; altera a Lei n.8.112, de 11 de dezembro de 1990; revoga a lei n.11.111, de 5 de maio de 2005, e dispositivos da Lei n. 8.159, de 8 de janeiro de 1991; e dá outras providências. Diário Oficial da União, Brasília, 19 de novembro de 2011. Disponível em: http://www.planalto.gov.br/ccivil_03/_ato2011-2014/2011/lei/l12527.htm. Acesso em: 31 de julho de 2015. 
SANTOS COIMBRA, Wilber Carlos dos. A evolução do constitucionalismo no brasil e a atuação contemporânea dos tribunais de contas. Revista Eletrônica Direito e Política, Programa de PósGraduação Stricto Sensu em Ciência Jurídica da UNIVALI, Itajaí, v.10, n.3, $2^{\circ}$ quadrimestre de 2015. Disponível em: www.univali.br/direitoepolitica - ISSN 1980-7791.

os Tribunais de Contas no espaço epicentral para concretude do controle social, encetado pelas normas de cujo jaez se faz digressão.

Daí caber, ressalvado maior aprofundamento não exauriente, concluir pela importância republicana dos Tribunais de Contas, cuja finalidade institucional vincula-se à ideologia jurídico-organizacional ideada pelo constitucionalismo brasileiro, reproduzindo, é verdade, as vertentes consolidadas aos longo da história do constitucionalismo mundial.

Por fim, infere-se que é tema exclusivo do constitucionalismo brasileiro, a prevalência normatizada do controle social, por manifestação institucional do Parlamento, as Cortes de Contas, por sua vez, alocam-se no tema como protagonistas, para atingir a meta-fim idealizada pelo controle social, mormente, relativa ao emprego dos recursos públicos, suportados pela sociedade para custear as despesas do Estado, forte em atingir sua finalidade precípua promanada da concepção clássica do Estado - o bem comum.

\section{CONSIDERAÇÕES FINAIS}

O presente artigo, longe de exaurir o tema, pretendeu demonstrar o surgimento do constitucionalismo, e, ao depois, sua formatação no Brasil, em cuja oportunidade se concluiu que desde a Constituição Federal de 1891 até a Constituição Federal de 1988, o constitucionalismo moderno impregnou a consciência constitucional brasileira; fez-se trazer a nova dogmática constitucional, faceta do constitucionalismo contemporâneo, que se convencionou chamar-se de neoconstitucionalismo de cuja hermenêutica advém as afirmações de que a Constituição deve ser o centro do sistema.

A Constituição, resultado dos primórdios do constitucionalismo formal originário, era vista muito mais como um documento político do que propriamente como um documento jurídico, vinculante e obrigatório. O constitucionalismo moderno, que surge com as matizes dos direitos sociais, não mais anuía com a formalidade da norma e com seu teor material, para produzir resultados sociais eficientes, 
SANTOS COIMBRA, Wilber Carlos dos. A evolução do constitucionalismo no brasil e a atuação contemporânea dos tribunais de contas. Revista Eletrônica Direito e Política, Programa de PósGraduação Stricto Sensu em Ciência Jurídica da UNIVALI, Itajaí, v.10, n.3, $2^{\circ}$ quadrimestre de 2015. Disponível em: www.univali.br/direitoepolitica - ISSN 1980-7791.

eficazes e efetivos. Contudo, na concretização das políticas públicas irradiadas do novo constitucionalismo, na gênese do século XIX, no Brasil, surge um órgão de notória qualificação técnica com a finalidade de atuar na fiscalização do emprego dos recursos públicos, despendidos para concretizar a vontade estatal, uma vez que já se exigia resultado na prestação dos serviços executados pelo Estado, que tinha toda a sociedade como meta-fim.

Reconhece-se na Constituição Federal vigente sua força imperativa, seu texto é norma jurídica dotada de superioridade e coercibilidade; suas normas possuem carga valorativa - axiológica - tais como a dignidade da pessoa humana e direitos fundamentais; possui eficácia irradiante em relação aos Poderes Públicos e mesmo aos particulares; impõe a concretização dos valores constitucionalizados e coage a que se garanta condições mínimas de dignidade a pessoa humana.

Fez-se mesclar, na pesquisa empreendida, que o surgimento dos Tribunais de Contas no Brasil, guarda perfeita sincronia com as nuances do constitucionalismo moderno e contemporâneo, uma vez que a nova ordem constitucional, reproduzindo regras de outrora, atribuem às Cortes de Contas brasileiras competências para fiscalizar a transparência da aplicação dos dinheiros públicos, nesse núcleo inserindo a correta e econômica aplicação, além da publicação ampla de tais execuções para conhecimento popular; há, ainda, em harmonia com os ideais democráticos, competência das Cortes de Contas para atuar na inibição preventiva de improbidade administrativa e de dano ao erário, podendo para tanto expedir tutelas de urgência e de evidência, sempre que for latente o receio de ameaça a bem público ou houver indícios de sua violação, competência esta decorrente da evolução constitucional do poder geral de cautela conferido pela CRFB/88.

Infere-se, destarte, que a partir da Constituição de 1988, a instituição Tribunal de Contas consolidou-se de tal forma para unicamente promover a defesa do patrimônio público: primário ou secundário, que o constituinte originário the emprestou uma estrutura exclusiva, uma vez que os Tribunais de Contas não 
SANTOS COIMBRA, Wilber Carlos dos. A evolução do constitucionalismo no brasil e a atuação contemporânea dos tribunais de contas. Revista Eletrônica Direito e Política, Programa de PósGraduação Stricto Sensu em Ciência Jurídica da UNIVALI, Itajaí, v.10, n.3, $2^{\circ}$ quadrimestre de 2015. Disponível em: www.univali.br/direitoepolitica - ISSN 1980-7791.

pertencem a nenhum dos três poderes, possuindo natureza jurídica de instituição autônoma, independente institucionalmente no seu mister.

Tal relevância se fez sentir de forma tão nítida, que a Suprema Corte Brasileira reconheceu em precedentes, que foram transformados em jurisprudência, e, por fim, editou o verbete Sumular n. $347^{42}$, em que reconhece a competência para apreciar a constitucionalidade de leis e atos do Poder Público; sob essa perspectiva jurídica, resta clarividente que as atribuições dos Tribunais de Contas ultrapassaram as discussões sobre a legalidade no controle orçamentário, financeiro, contábil operacional e patrimonial, fortalecendo-se a atribuição de fiscalização baseada na legitimidade do órgão e no princípio da economicidade, adequando-se com perfeição aos ditames do constitucionalismo moderno e contemporâneo.

\section{REFERÊNCIAS DAS FONTES CITADAS}

AGUIAR, Ubiratan Diniz de; ALBUQUERQUE, Marcio André Santos de; MEDEIROS, Paulo Henrique Ramos. A administração pública sob a perspectiva do controle externo. Belo Horizonte: Fórum, 2011.

ARISTÓTELES. A Política. Tradução de Nestor Silveira. São Paulo: Folha de S. Paulo, 2010.

BARROSO, Luís Roberto. Curso de Direito Constitucional Contemporâneo: os conceitos fundamentais e a construção do novo modelo. 4. ed. São Paulo: Saraiva, 2013.

BASTOS, Celso Ribeiro. Curso de direito constitucional. 20. ed. atual. São Paulo: Saraiva, 1999.

BONAVIDES, Paulo. Curso de Direito Constitucional. 23. ed. São Paulo: Malheiros, 2008.

BRANCO, Paulo Gustavo Gonet. Curso de direito constitucional. 4.ed. São Paulo: Saraiva, 2009.

42 BRASIL. Supremo Tribunal Federal. Súmula n. 347. O Tribunal de Contas, no exercício de suas atribuições, pode apreciar a constitucionalidade das leis e atos do poder público. Disponível em:

http://www.stf.jus.br/portal/cms/verTexto.asp?servico=jurisprudenciaSumula\&pagina=sumula_3 01_400. Acesso em: 31 de julho de 2015. 
SANTOS COIMBRA, Wilber Carlos dos. A evolução do constitucionalismo no brasil e a atuação contemporânea dos tribunais de contas. Revista Eletrônica Direito e Política, Programa de PósGraduação Stricto Sensu em Ciência Jurídica da UNIVALI, Itajaí, v.10, n.3, 20 quadrimestre de 2015. Disponível em: www.univali.br/direitoepolitica - ISSN 1980-7791.

BRASIL. Constituição da República Federativa do Brasil de 1981. Disponível em: http:// www.planalto.gov.br/ccivil_03/Constituicao/Constituicao91.htm. Acesso em: 05 de julho. 2015.

\section{BRASIL. Constituição da República Federativa do Brasil de 1988.} Disponível

http://www.planalto.gov.br/ccivil_03/constituicao/constituicao.htm. Acesso em: 25 de julho de 2015.

BRASIL. Decreto n.0 966-A, de 07 de novembro de 1890. Crêa um Tribunal de Contas para o exame, revisão e julgamento dos actos concernentes á receita e despeza da Republica. Coleção de Leis do Brasil - 1890, Página 3440 Vol. Fasc. XI (Publicação Original).Disponível em:http://www2.camara.leg.br/legin/fed/decret/1824-1899/decreto-966-a-7novembro-1890-553450-norma-pe.html. Acesso em: 05 de julho de 2015.

BRASIL. Lei Complementar n. 131, de 27 de maio de 2009. Acrescenta dispositivos à Lei Complementar $\mathrm{n}^{\circ}$ 101, de 4 de maio de 2000, que estabelece normas de finanças públicas voltadas para a responsabilidade na gestão fiscal e dá outras providências, a fim de determinar a disponibilização, em tempo real, de informações pormenorizadas sobre a execução orçamentária e financeira da União, dos Estados, do Distrito Federal e dos Municípios. Diário Oficial da União, Brasília/DF, p. 2, 28 de maio de 2009. Disponível em: http://www.planalto.gov.br/ccivil_03/leis/LCP/Lcp131.htm . Acesso em: 31 de julho de 2015.

BRASIL. Lei n.12.527, de 18 de novembro de 2011. Regula o acesso a informações previsto no inciso XXXIII do artigo 50, no inciso II do \& $3^{\circ}$ do art. 37 e no \& $2^{\circ}$ do art.216 da Constituição Federal; altera a Lei n.8.112, de 11 de dezembro de 1990; revoga a lei n.11.111, de 5 de maio de 2005, e dispositivos da Lei n. 8.159, de 8 de janeiro de 1991; e dá outras providências. Diário Oficial da União, Brasília, 19 de novembro de 2011. Disponível em: http://www.planalto.gov.br/ccivil_03/_ato2011-2014/2011/lei/l12527.htm.

Acesso em: 31 de julho de 2015.

BRASIL. Lei no 8.429 de 02 de junho de 1992. Dispõe sobre as sanções aplicáveis aos agentes públicos nos casos de enriquecimento ilícito no exercício de mandato, cargo, emprego ou função na administração pública direta, indireta ou fundacional e dá outras providências. Diário Oficial da União, Brasília, DF, ano 130, n. 105, 03 de junho de 1992. Seção I, p.1. Disponível em: http://www.planalto.gov.br/ccivil_03/LEIS/L8429.htm. Acesso em: 31 de julho de 2015.

BRASIL. Supremo Tribunal Federal. Súmula n. 347. O Tribunal de Contas, no exercício de suas atribuições, pode apreciar a constitucionalidade das leis e atos do poder público. Disponível em:http://www.stf.jus.br/portal/cms/verTexto.asp?servico=jurisprudenciaSumul a\&pagina=sumula_301_400. Acesso em: 31 de julho de 2015. 
SANTOS COIMBRA, Wilber Carlos dos. A evolução do constitucionalismo no brasil e a atuação contemporânea dos tribunais de contas. Revista Eletrônica Direito e Política, Programa de PósGraduação Stricto Sensu em Ciência Jurídica da UNIVALI, Itajaí, v.10, n.3, $2^{\circ}$ quadrimestre de 2015. Disponível em: www.univali.br/direitoepolitica - ISSN 1980-7791.

CANOTILHO, José Joaquim Gomes. Direito constitucional e teoria da constituição 7. ed. Coimbra: Edições Almedina. 2003.

CRUZ, Paulo Márcio. Política, Poder, Ideologia e Estado Contemporâneo. 3. ed. $1^{\text {a }}$ tir. Curitiba: Juruá, 2003.

CUNHA, Paulo Ferreira da. Do Constitucionalismo Brasileiro: uma introdução histórica (1824-1998). Historia Constitucional, núm. 8, septiembre-, 2007, pp. 263-

271.Disponívelem <http://biblioteca.universia.net/html_bura/ficha/params/id/29 142206.html>. Acesso em 10 de julho de. 2015.

FAUSTO, Boris. História do Brasil. 12. ed. São Paulo: Editora da Universidade de São Paulo, 2004.

FERNANDES, Jorge Ulisses Jacoby. Tribunais de Contas do Brasil: jurisdição e competência. 2.ed. Belo Horizonte: Fórum, 2008.

FERRAJOLI, Luigi. Democracia constitucional y Derechos Fundamentales. In: - Democracia y garantismo. Tradução de Perfecto A. Ibáñes, et al. Madrid: Trotta, 2008.

FERREIRA, Luís Pinto. Princípios Gerais do Direito Constitucional Moderno. 6. ed. São Paulo: Saraiva, v. 1, 1983.

GOMES, Ademar Martins Bento. A trajetória dos Tribunais de Contas: estudos sobre a evolução do controle externo da administração pública. Salvador: Tribunal de Contas do Estado da Bahia, 2002.

HESPANHA, António Manuel. As vésperas do Leviathan: instituições e poder político, Portugal (século XVII). Coimbra: Almedina, 1994.

JACQUES, Paulino. Curso de Direito Constitucional, 5. ed., Rio de Janeiro: Forense, 1957.

LOEWENSTEIN, Karl. Teoría de la Constitución. Tradução de Alfredo Gallego Anabitarte. 2 ed. Barcelona: Ariel, 1970.

MENDES, Gilmar Ferreira; COELHO, Inocêncio Mártires; BRANCO, Paulo Gustavo Gonet. Curso de direito constitucional. 4.ed. São Paulo: Saraiva, 2009.

MENDONÇA, Marcos Carneiro de. O Erário Régio no Brasil. Rio de Janeiro: Ministério da Justiça, 1968.

PASOLD, Cesar Luiz. Metodologia da Pesquisa Jurídica: teoria e prática. 12 ed. São Paulo: Conceito Editorial, 2011.

PECCES-BARBA, Gregorio. La diacronía del fundamento y del concepto de los Derechos: el tempo de la historia. In: __. Curso de Derechos Fundamentales: teoria general. Madrid: Universidad Carlos III de Madrid, 1995. 
SANTOS COIMBRA, Wilber Carlos dos. A evolução do constitucionalismo no brasil e a atuação contemporânea dos tribunais de contas. Revista Eletrônica Direito e Política, Programa de PósGraduação Stricto Sensu em Ciência Jurídica da UNIVALI, Itajaí, v.10, n.3, $2^{\circ}$ quadrimestre de 2015. Disponível em: www.univali.br/direitoepolitica - ISSN 1980-7791.

PISARELLO, Gerardo. Los derechos sociales y sus garantias: elementos para uma reconstrucción. Madrid, 1995.

PONTES DE MIRANDA, Francisco Cavalcanti. Comentários à Constituição de 1967: com a EC n.01, de 1969. 2. ed. São Paulo: Revista dos Tribunais, 1970, t.III, POZZOLO, Susanna. Neoconstitucionalismo y Especificidad de la Interpretación Constitucional, in Doxa: Cuadernos del filosia del derecho. Espanha: Doxa 21-II, 1998.

SANCHÍS, Luis Pietro. La teoria del Derecho em tiempos de constitucionalismo. In: CARBONELL, Miguel (Ed.). Neoconstitucionalismo(s). Madrid: Trotta, 2003.

SARLET, Ingo Wolfgang; curso de direito constitucional. 2. ed. São Paulo; Editora Revista dos Tribunais, 2013.

SILVA, Jóse Afondo da. Curso de Direito Constitucional Positivo. 9. ed. São Paulo: Malheiros Editores, 1993.

TAVARES, André Ramos. Curso de Direito Constitucional. 10 aed. São Paulo: Saraiva, 2012.

VIEIRA, José Ribas. Introdução ao pensamento de Benjamin Constant. In: REBECQUE, Henri Benjamin Constant de. Princípios políticos constitucionais. Tradução: Maria do Céu Carvalho. Rio de Janeiro: Liber Juris, 1989.

WEHLING, Arno. Administração portuguesa no Brasil, 1777-1808. Brasília: Funcep, 1986.

Submetido em: Julho/2015

Aprovado em: Agosto/2015 